\title{
MY READING LIST FOR BEING LESS POLITICALLY IGNORANT
}

\author{
Nguyen Thanh Thanh Huyen \\ Centre for Interdisciplinary Social Research \\ Phenikaa University \\ Yen Nghia, Ha Dong district, Hanoi 100803, Vietnam

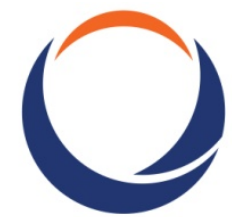 \\ PHENIKAA \\ U N I VER S I T Y
}

September 22, 2021

A few months ago, with the 2021 Legislative Election, I felt compelled to understand my role as a voter in my country, The Socialist Republic of Vietnam. Although I have voted in two national elections, the recent election was indeed a strange and nuanced experience to me. The reader may find me politically ignorant, and I admit that I am, and I have never been truly enthusiastic about politics. But with my own experience with the 2021 Legislative Election, I am convinced that I need to fix that attitude sooner or later because of how potentially political factors will affect my life.

But first, I will walk you through my personal experience with the national elections. The first one happened when I had not yet graduated from high school, and I could barely remember anything except choosing random names on my vote card. Perhaps, my vague memories with the national election allowed history to happen again. The second election was not so different from the first, despite that the election committee provided more information about the candidates.

I scanned through the faces of strangers with good educational backgrounds and respectable jobs, but I had no idea I should vote for whom. Their education and occupation may give me some clues about their characters and political inclinations, but they were still pure guesses. Due to the lack of campaign and effective political communication during the national elections, the utmost important questions such as "Who will they vote for?", "What will they do as government officers?" had no answer. 
As such, I ended up choosing random candidates again. I voted irresponsibly and lacked knowledge about the representatives, even though I knew that these representatives chose the people who would influence almost every aspect of my life.

Irresponsible voting is such an ironic act of a citizen in a republic country. And for a descendant of those who had fought relentlessly against feudalism and colonialism for the right to vote, it is ungrateful when taking that right for granted. And personally, because the actions of elected representatives could adversely affect my life somehow, I want to avoid the chance of voting for the wrong people.

However, it is too late to do some research about the elected representatives. Hence, I decided to learn more about the four most important people whom the elected representatives had given their trust to in the last national election.

In Vietnam, the four most important positions in the government (in Vietnamese: tú tru) are the general secretary (GS), the chairman of the National Assembly (CNA), the prime minister (PM), and the president (PR). The incumbent officers are Nguyễn Phú Trọng (GS), Vương Đình Huệ (CNA), Phạm Minh Chính (PM), and Nguyễn Xuân Phúc (PR).

Reading their works could be a convenient and accessible way to learn about their political orientation and ideologies. The table shows some of their works that I collected.

Table 1. My reading list for being less political ignorant

\begin{tabular}{|l|l|l|}
\hline No & \multicolumn{1}{|c|}{ Title } & \multicolumn{1}{|c|}{ Author } \\
\hline 1 & $\begin{array}{l}\text { Toàn Đảng, toàn dân chung sức, đồng lòng xây } \\
\text { dựng đất nước ta ngày càng phồn vinh, hạnh phúc } \\
\text { (Together, the Party and the People will have a } \\
\text { prosperous and happy nation) [1] }\end{array}$ & Nguyễn Phú Trọng \\
\hline 2 & $\begin{array}{l}\text { Xây dựng, chỉnh đốn Đảng là nhiệm vụ then chốt } \\
\text { để phát triển đất nước } \\
\text { (Developing and regulating the Party is the key } \\
\text { mission to build the country) [2] }\end{array}$ & Nguyễn Phú Trọng \\
\hline 3 & $\begin{array}{l}\text { Kinh tế Việt Nam: Thăng trầm và Đột Phá } \\
\text { (Vietnam Economy: Its Turbulance and } \\
\text { Breakthrough) [3] }\end{array}$ & $\begin{array}{l}\text { Phạm Minh Chính, Vương } \\
\text { Quân Hoàng }\end{array}$ \\
\hline 4 & $\begin{array}{l}\text { Về cán bộ và công tác cán bộ (About government } \\
\text { officers and their responsibilities) [4] }\end{array}$ & $\begin{array}{l}\text { Phạm Minh Chính, Nguyễn } \\
\text { Xuân Thắng, Đoàn Minh } \\
\text { Huấn (Editors) }\end{array}$ \\
\hline
\end{tabular}


As the listed books are not just about politics but also the Vietnamese economy, I hope that this list will help me grasp the political and economic policies that are currently implemented or could take place in the future.

\section{References}

[1] Trọng, N. P. (2021). Toàn Đảng, toàn dân chung sức, đồng lòng xây dựng đất nước ta ngày càng phồn vinh, hạnh phúc. Nxb Chính trị Quốc gia Sự thật, Hà Nội.

[2] Trọng, N. P. (2021). Xây dựng, chỉnh đốn Đảng là nhiệm vụ then chốt để phát triển đât nước. Nhà Xuất bản Chính trị Quốc gia Sự thật, Hà Nội.

[3] Chính, P. M., \& Hoàng, V. Q. (2009). Kinh tế Việt Nam: Thăng trầm và đột phá. Nxb Chính trị Quốc gia, Hà Nội.

[4] Chính, P. M., Thắng, N. X., \& Huấn, Đ. M. (2018). Về cán bộ và công tác cán bộ. Nxb Chính trị Quốc gia Sự thật, Hà Nội. 